\title{
PERKEMBANGAN MUTAKHIR PENDIDIKAN BAHASA INDONESIA: KURIKULUM 2013 SEKOLAH DASAR
}

\author{
Neneng Sri Wulan \\ Universitas Pendidikan Indonesia Kampus Serang \\ Jl. Ciracas No. 18 Serang Banten \\ Email: neneng_sri_wulan@upi.edu
}

\begin{abstract}
Despite changes intended to improve educational curriculum to better direction but in the process of implementation still experiencing problems. Many things that cause it. One is the lack of understanding of the particulars of the curriculum in 2013 particularly for learning Indonesian language and literature. There are still many elementary school teachers who have not mastered, even understand it. Based on observations made in Banten province, nearly 50\% of primary school teachers do not understand the particulars of learning Indonesian language and literature in the curriculum in 2013. It is certainly very unfortunate, because the teacher is one of the cornerstones of educational success. If teachers do not understand and master the curriculum to be applied in the classroom, of course it will have an impact on student learning outcomes. Therefore the discussion of learning Indonesian language and literature for primary school based curriculum in 2013 is certainly very important and necessary for practitioners, especially those that work in the world of elementary school. Discussion about learning Indonesian language and literature based curriculum in 2013 is expected to be one of the doors to open insight, understanding, and mastery, which will have an impact on learning outcomes over the maximum. Keywords: learning Indonesian language and literature, elementary school, curriculum 2013.
\end{abstract}

Meskipun perubahan kurikulum dimaksudkan untuk mengembangkan pendidikan ke arah yang lebih baik, namun dalam proses pelaksanaannya tetap mengalami permasalahan. Banyak hal yang menyebabkan terjadinya hal tersebut. Salah satunya adalah kurang pemahaman mengenai ihwal kurikulum 2013, khususnya untuk pembelajaran Bahasa dan Sastra Indonesia. Masih banyak guru sekolah dasar yang belum menguasai, bahkan memahami hal tersebut. Berdasarkan observasi yang dilakukan di provinsi Banten, hampir 50\% guru sekolah dasar belum memahami ihwal pembelajaran Bahasa dan Sastra Indonesia dalam kurikulum 2013. Hal tersebut tentu sangat disayangkan, karena guru merupakan salah satu tonggak keberhasilan pendidikan. Bila guru belum memahami dan menguasai kurikulum yang harus diaplikasikannya di dalam kelas, tentu hal tersebut akan berdampak pada hasil belajar siswa. Oleh karena itu, pembahasan mengenai pembelajaran Bahasa dan Sastra Indonesia untuk sekolah dasar berdasarkan Kurikulum 2013 tentu sangat penting dan dibutuhkan bagi para praktisi, khususnya yang bergelut di dunia sekolah dasar. Pembahasan mengenai pembelajaran Bahasa dan Sastra Indonesia berdasarkan Kurikulum 2013 diharapkan dapat menjadi salah satu pintu untuk membuka wawasan, pemahaman, dan penguasaan, yang nantinya akan berdampak pada hasil pembelajaran yang lebih maksimal.

Kata kunci: pembelajaran bahasa dan sastra Indonesia, sekolah dasar, kurikulum 2013.

PENDAHULUAN Kurikulum merupakan suatu elemen yang tidak dapat dipisahkan dari pendidikan. Kurikulum adalah rancangan ideal yang dibuat untuk mencapai tujuan-tujuan tertendu di dalam pendidikan. Menurut
Sukmadinata (1999), setiap praktik pendidikan diarahkan pada pencapaian tujuan-tujuan tertentu. Pedoman untuk pencapaian tujuantujuan tersebut adalah kurikulum. Menurut Beauchamp (Sukmadinata, 1999), kurikulum 
adalah suatu rencana pendidikan atau pengajaran. Terdapat tiga konsep kurikulum (Sukmadinata,1999), yaitu kurikulum sebagai substansi, kurikulum sebagai suatu sistem, dan kurikulum sebagai suatu bidang studi

Perkembangan kurikulum di Indonesia terjadi dari masa ke masa. Setiap perkembangan tersebut bertujuan untuk mengembangkan pendidikan ke arah yang lebih baik. Perkembangan kurikulum yang terjadi di Indonesia biasanya berkaitan dengan adanya pergantian kurikulum. Setiap kurikulum yang pernah diimpelementasikan di Indonesia memiliki karakteristik yang berbeda, misalnya dari segi isi. Isi yang dimaksud dalam makalah ini berkaitan dengan substansi materi pelajaran.

Kurikulum 2013 merupakan kurikulum terbaru yang diaplikasikan di Indonesia. Kurikulum ini pun tidak terlepas dari kebaruan isi, misalnya pada substansi materi pelajaran Bahasa Indonesia. Pada pelajaran Bahasa Indonesia, terdapat perubahan materi yang berbeda dari kurilum-kurikulum sebelumnya. Perubahan tersebut dapat dikatakan cukup signifikan, terutama pada jenjang pendidikan sekolah dasar. Selain adanya penambahan jam pelajaran Bahasa Indonesia, isi materi ajarnya pun sedikit berbeda.

Perkembangan substansi tersebut sangat menarik untuk dikaji. Oleh karena itu, penelitian ini dilakukan untuk mengkaji perubahan dan perkembangan yang terjadi pada mata pelajaran Bahasa Indonesia dalam Kurikulum 2013. Penelitian ini berupaya mendeskripsikan (1) pembelajaran Bahasa Indonesia jenjang sekolah dasar pada Kurikulum 2013, dan (2) isi buku siswa dan buku siswa sekolah dasar pada Kurikulum 2013, dan (3) aplikasi Kurikulum 2013 pada jenjang sekolah dasar, khususnya di provinsi Banten.

\section{METODE}

Metode penelitian yang digunakan dalam penelitian ini adalah metode deskriptif kualitatif. Metode ini digunakan untuk mendeksripsikan data-data yang telah dikumpulkan dan dianalisis. Teknik pengumpulan data yang digunakan dalam penelitian ini adalah studi dokumentasi, observasi, dan angket. Studi dokumentasi dilakukan untuk mendapatkan data mengenai pembelajaran Bahasa Indonesia dalam Kurikulum 2013. Angket dan observasi dilakukan untuk mendapatkan data mengenai aplikasi Kurikulum 2013, khususnya di provinsi Banten.

\section{HASIL DAN PEMBAHASAN}

Perbandingan Pembelajaran Bahasa Indonesia Sekolah Dasar dalam Kurikulum Berbasis Kompetensi, Kurikulum Tingkat Satuan Pendidikan, dan Kurikulum 2013

Pada Kurikulum Berbasis Kompetensi (KBK), mata pelajaran Bahasa Indonesia mempunyai alokasi waktu terbanyak, yaitu sepulun jam per minggu untuk kelas 1 dan 2, enam jam per minggu untuk kelas 4-6 enam jam. Pelajaran Bahasa Indonesia memiliki fungsi dan tujuan sebagai beirkut.

a. Fungsi mata pelajaran bahasa dan sastra Indonesia dalam KBK adalah (1) sarana pembinaan persatuan dan kesatuan bangsa; (2) sarana peningkatan pengetahuan dan keterampilan dalam rangka pelestarian dan pengembangan budaya; (3) sarana peningkatan iptek dan seni; (4) sarana penyebarluasan pemakaian bahasa Indonesia untuk berbagai keperluan; (5) sarana pengembangan penalaran; (6) sarana pemahaman beragam budaya Indonesia melalui kesusastraan Indonesia.

b. Tujuan umum pembelajaran bahasa Indonesia SD dalam KBK adalah (1) siswa menghargai dan membanggakan bahasa Indonesia sebagai bahasa persatuan dan bahasa negara; (2) siswa memahami bahasa Indonesia dari segi bentuk, makna, dan fungsi, serta menggunakannya dengan tepat dan kreatif dalam bermacam-macam tujuan; (3) siswa memiliki kemampuan menggunakan bahasa Indonesia untuk meningkatkan kemampuan intelektual, kematangan emosional, dan sosial; (4) siswa memiliki disiplin dalam berpikir dan berbahasa; (5) siswa mampu menikmati dan memanfaatkan karya sastra untuk mengembangkan kepribadian, wawasan kehidupan, meningkatkan kemampuan berbahasa, dan (6) siswa menghargai dan membanggakan sastra Indonesia sebagai khasanah budaya dan intelektual. (KBK, mata pelajaran Bahasa Indonesia SD, Puskur Balitbang Depdiknas 2002). 
Di dalam KBK, mata pelajaran Bahasa Indonesia SD memiliki enam aspek kompetensi umum, yaitu sebagai berikut.

a. Mendengarkan

Berdaya tahan dalam konsentrasi mendengarkan selama tiga puluh menit, dan mampu menyerap gagasan pokok, perasaan dari cerita, berita, dan lain-lain, yang didengar serta mampu memberikan respons secara tepat.

b. Berbicara

Mengungkapkan gagasan dan perasaan, menyampaikan sambutan, berdialog, menyampaikan pesan, bertukar pengalaman, menjelaskan, mendeskripsikan, dan bermain peran.

c. Membaca

Membaca lancar beragam teks dan mampu menjelaskan isinya.

d. Menulis

Menulis karangan naratif dan nonnaratif dengan tulisan yang rapi dan jelas dengan menggunakan kosakata, kalimat, ejaan yang benar sehingga dapat dipahami oleh pembaca.

e. Kebahasaan

Memahami/ menggunakan kalimat lengkap, tak lengkap, dalam berbagai konteks, imbuhan, penggunaan kosakata, jenis kata, ejaan, pelafalan, serta intonasi bahasa Indonesia.

f. Apresiasi Bahasa dan Sastra Indonesia

Mengapresiasi dan berekspresi sastra melalui kegiatan mendengarkan, menonton, membaca, dan melisankan hasil sastra berupa dongeng, puisi, darama pendek, serta menulis cerita dan puisi.

Pembelajaran Bahasa Indonesia yang termuat dalam KBK tidak terlalu berbeda dengan KTSP. Berdasarkan pada Panduan Kurikulum Tingkat Satuan Pendidikan(KTSP) SD/MI (2006:22) , mata pelajaran Bahasa Indonesia bertujuan agar peserta didik memiliki kemampuan sebagai berikut.

1. Berkomunikasi secara efektif dan efisien sesuai dengan etika yang berlaku, baik secara lisan maupun tulisan.
2. Menghargai dan bangga menggunakan Bahasa Indonesia sebagai bahasa pemersatu dan bahasa Negara.

3. Memahami Bahasa Indonesia dan menggunakannya dengan tepat dan kreatif untuk berbagai tujuan.

4. Menggunakan Bahasa Indonesia untuk meningkatkan kemampuan intelektual, serta kematangan emosional dan sosial.

5. Menikmati dan memanfaatkan karya sastra untuk memperhalus budi pekerti, serta meningkatkan pengetahuan dan kemampuan berbahasa.

6. Menghargai dan membanggakan sastra Indonesia sebagai khasanah budaya dan intelektual manusia Indonesia.

Dari deskripsi tersebut dapat terlihat bahwa pembelajaran Bahasa Indonesia pada jenjang sekolah dasar dalam KBK dan KTSP memang tidak terlalu berbeda. Hal tersebut mengalami perubahan pada Kurikulum 2013. Pada Kurikulum 2013 sekolah dasar, Bahasa Indonesia berperan sebagai penghela. Penghela dimaksudkan sebagai alat untuk mengantarkan esensi materi dari semua mata pelajaran. Kandungan materi mata pelajaran yang lain dijadikan sebagai konteks dalam dalam pelajaran Bahasa Indonesia.

\section{Struktur Kurikulum 2013 pada Pembelajaran Bahasa Indonesia Sekolah Dasar}

Struktur kurikulum adalah juga gambaran mengenai penerapan prinsip kurikulum mengenai posisi seorang peserta didik dalam menyelesaikan pembelajaran di suatu satuan atau jenjang pendidikan. Dalam struktur kurikulum menggambarkan ide kurikulum mengenai posisi belajar seorang peserta didik yaitu apakah mereka harus menyelesaikan seluruh mata pelajaran yang tercantum dalam struktur ataukah kurikulum memberi kesempatan kepada peserta didik untuk menentukan berbagai pilihan. Struktur kurikulum terdiri atas sejumlah mata pelajaran, dan beban belajar (Depdikbud, 2013).

Berikut ini adalah struktur kurikulum 2013 untuk jenjang sekolah dasar. 
Tabel 1. Struktur Kurikulum 2013 Untuk Jenjang Sekolah Dasar

\begin{tabular}{|l|c|c|c|c|c|c|c|c|c|}
\hline \multirow{2}{*}{\multicolumn{2}{|c|}{ MATA PELAJARAN }} & \multicolumn{5}{c|}{ ALOKASI WAKTU BELAJAR } \\
\cline { 2 - 8 } & I & II & III & IV & V & VI \\
\hline Kelompok A & \multicolumn{5}{|c|}{ AER MINGGU } \\
\hline 1. & Pendidikan Agama dan Budi Pekerti & 4 & 4 & 4 & 4 & 4 & 4 \\
\hline 2. & Pendidikan Pancasila dan Kewarganegaraan & 5 & 5 & 6 & 4 & 4 & 4 \\
\hline 3. & Bahasa Indonesia & 8 & 9 & 10 & 7 & 7 & 7 \\
\hline 4. & Matematika & 5 & 6 & 6 & 6 & 6 & 6 \\
\hline 5. & Ilmu Pengetahuan Alam & - & - & - & 3 & 3 & 3 \\
\hline 6. & Ilmu Pengetahuan Sosial & - & - & - & 3 & 3 & 3 \\
\hline Kelompok B & & & & & & \\
\hline 1. & Seni Budaya dan Prakarya & 4 & 4 & 4 & 5 & 5 & 5 \\
\hline 2. & Pendidikan Jasmani, Olah Raga dan Kesehatan & 4 & 4 & 4 & 4 & 4 & 4 \\
\hline Jumlah Alokasi Waktu Per Minggu & $\mathbf{3 0}$ & $\mathbf{3 2}$ & $\mathbf{3 4}$ & $\mathbf{3 6}$ & $\mathbf{3 6}$ & $\mathbf{3 6}$ \\
\hline
\end{tabular}

(Sumber: Depdikbud, 2013)

Selain kegiatan intrakurikuler seperti yang tercantum di dalam struktur kurikulum tersebut, terdapat pula kegiatan ekstrakurikuler SD/MI antara lain Pramuka (Wajib), Usaha Kesehatan Sekolah, dan Palang Merah Remaja. Mata pelajaran Kelompok A adalah kelompok mata pelajaran yang kontennya dikembangkan oleh pusat. Mata pelajaran Kelompok B yang terdiri atas mata pelajaran Seni Budaya dan Prakarya serta Pendidikan Jasmani, Olahraga, dan Kesehatan adalah kelompok mata pelajaran yang kontennya dikembangkan oleh pusat dan dilengkapi dengan konten lokal yang dikembangkan oleh pemerintah daerah. (Depdikbud, 2013).

Dari struktur tersebut dapat terlihat beban belajar siswa. Beban belajar di SD kelas I, II, dan III adalah 30, 32, 34 sedangkan untuk kelas IV, V, dan VI adalah 36 jam setiap minggu. Jam belajar yang berlaku di sekolah dasar adalah 35 menit. Jam belajar siswa sekolah dasar pada Kurikulum 2013 lebih banyak dibandingankan dengan kurikulum sebelum. Menurut Depdikbud (2103), dengan adanya tambahan jam belajar ini dan pengurangan jumlah Kompetensi Dasar, guru memiliki keleluasaan waktu untuk mengembangkan proses pembelajaran yang berorientasi siswa aktif. Proses pembelajaran siswa aktif memerlukan waktu yang lebih panjang dari proses pembelajaran penyampaian informasi karena peserta didik perlu latihan untuk mengamati, menanya, mengasosiasi, dan berkomunikasi. Proses pembelajaran yang dikembangkan menghendaki kesabaran guru dalam mendidik peserta didik sehingga mereka menjadi tahu, mampu dan mau belajar dan menerapkan apa yang sudah mereka pelajari di lingkungan sekolah dan masyarakat sekitarnya. Selain itu bertambahnya jam belajar memungkinkan guru melakukan penilaian proses dan hasil belajar.

Dari struktur kurikulum tersebut, dapat terlihat pula bahwa Bahasa Indonesia merupakan mata pelajaran dengan jam terbanyak. Mata pelajaran Bahasa Indonesia memiliki empat kompetensi inti. Kompetensi inti yang pertama untuk kelas I, II, III, IV, V, dan VI adalah menerima, menjalankan, dan menghargai ajaran agama yang dianutnya. Esensi kompetensi inti kedua untuk kelas I, II, III, dan IV adalah memiliki perilaku jujur, disiplin, tanggung jawab, santun, peduli, dan percaya diri dalam berinteraksi dengan keluarga, teman, dan guru. Kompetensi inti kedua untuk kelas V dan VI adalah menunjukkan perilaku jujur, disiplin, tanggung jawab, santun, peduli, dan percaya diri dalam berinteraksi dengan keluarga, teman, guru, dan tetangganya serta cinta tanah air.. Kompetensi inti ketiga untuk kelas I, II, dan III adalah memahami pengetahuan faktual dengan cara mengamati [mendengar, melihat, membaca] dan menanya berdasarkan rasa ingin tahu tentang dirinya, makhluk ciptaan Tuhan dan kegiatannya, dan benda-benda yang 
dijumpainya di rumah dan di sekolah. Kompetensi inti ketiga untuk kelas IV, V, dan VI adalah memahami pengetahuan faktual dengan cara mengamati dan menanya berdasarkan rasa ingin tahu tentang dirinya, makhluk ciptaan Tuhan dan kegiatannya, dan benda-benda yang dijumpainya di rumah, di sekolah dan tempat bermain. Kompetensi inti keempat untuk kelas I, dan II adalah menyajikan pengetahuan faktual dalam bahasa yang jelas dan logis, dalam karya yang estetis, dalam gerakan yang mencerminkan anak sehat, dan dalam tindakan yang mencerminkan perilaku anak beriman dan berakhlak mulia. Kompetensi inti keempat untuk kelas III adalah menyajikan pengetahuan faktual dalam bahasa yang jelas, sistematis dan logis, dalam karya yang estetis, dalam gerakan yang mencerminkan anak sehat, dan dalam tindakan yang mencerminkan perilaku anak beriman dan berakhlak mulia. Kompetensi inti keempat untuk kelas IV, V, dan VI adalah memahami pengetahuan faktual dengan cara mengamati dan menanya berdasarkan rasa ingin tahu tentang dirinya, makhluk ciptaan Tuhan dan kegiatannya, dan benda-benda yang dijumpainya di rumah, di sekolah dan tempat bermain. Dari kompetensi inti tersebut tampak bahwa KI 1 bertujuan untuk membidik sikap keagamaan, KI 2 membidik sikap social, KI 3 membidik pengetahuan, dan KI 4 membidik penerapan pengetahuan.

Setiap kompetensi tersebut memiliki kompetensi dasar (KD) yang berbeda-beda. Setelah memetakan dan menganalisis KI dan KD mata pelajaran Bahasa Indonesia, berikut adalah rancangan pembelajaran Bahasa Indonesia SD pada Kurikulum 2013.

1. Pembelajaran yang dirancang dalam Kurikulum 2013 adalah pembelajaran berbasis teks. Teks dihadirkan sebagai materi yang akan dikaji untuk berbagai mata pelajaran, begitu pula untuk mata pelajaran Bahasa Indonesia.

2. Empat aspek keterampilan berbahasa, yaitu menyimak, membaca, menulis, dan berbicara sudah terbidik di dalam kurikulum. Hal yang masih kurang tergali adalah aspek ilmu kebahasaan. Pembelajaran bahasa memang harus menekankan pada pengembangan empat keterampilan berbahasa. Namun, bila siswa tidak dibekali dengan ilmu kebahasaan yang memadai, maka pengembangan empat keterampilan berbahasa cenderung akan menjadi kurang maksimal.

3. Materi pembelajaran sastra dalam Kurikulum 2013 lebih sedikit dibandingkan dengan sebelumnya. Berikut adalah materi pembelajaran sastra di sekolah dasar dalam kurikulum 2013.

a. Kelas II

3.4 Mengenal teks lirik puisi tentang alam semesta dan penampakannya dengan bantuan guru atau teman dalam bahasa Indonesia lisan dan tulis yang dapat diisi dengan kosakata bahasa daerah untuk membantu pemahaman

4.4 Melantunkan dan menyajikan teks lirik puisi tentang alam semesta dan penampakannya secara mandiri dalam bahasa Indonesia lisan dan tulis yang dapat diisi dengan kosakata bahasa daerah untuk membantu penyajian

b. Kelas III

3.4 Menggali informasi dari teks dongeng tentang kondisi alam dengan bantuan guru atau teman dalam bahasa Indonesia lisan dan tulis yang dapat diisi dengan kosakata bahasa daerah untuk membantu pemahaman

4.4 Menyampaikan teks dongeng tentang kondisi alam dalam bentuk permainan peran secara mandiri dalam bahasa Indonesia lisan dan tulis yang dapat diisi dengan kosakata bahasa daerah untuk membantu penyajian

\section{c. Kelas IV}

3.4 Menggali informasi dari teks cerita petualangan tentang lingkungan dan sumber daya alam dengan bantuan guru dan teman dalam bahasa Indonesia lisan dan tulis dengan memilih dan memilah kosakata baku

4.4 Menyajikan teks cerita petualangan tentang lingkungan dan sumber daya alam secara mandiri dalam teks bahasa Indonesia lisan dan tulis dengan memilih dan memilah kosakata baku

d. Kelas V

3.4 Menggali informasi dari teks pantun dan syair tentang bencana alam serta kehidupan berbangsa dan bernegara dengan bantuan guru dan teman dalam bahasa Indonesia lisan dan tulis dengan memilih dan memilah kosakata baku

4.4 Melantunkan dan menyajikan teks pantun dan syair tentang bencana alam serta kehidupan berbangsa dan bernegara secara mandiri dalam 
bahasa Indonesia lisan dan tulis dengan memilih dan memilah kosakata baku

e. Kelas VI

3.4 Menggali informasi dari teks cerita fiksi sejarah tentang keutuhan wilayah nusantara Indonesia dan hubungannya dengan negara tetangga dengan bantuan guru dan teman dalam bahasa Indonesia lisan dan tulis dengan memilih dan memilah kosakata baku

4.4 Mengolah dan menyajikan teks cerita fiksi sejarah tentang keutuhan wilayah nusantara Indonesia dan hubungannya dengan negara tetangga secara mandiri dalam bahasa Indonesia lisan dan tulis dengan memilih dan memilah kosakata baku

Dari pemaparan tersebut tampak bahwa pembelajaran sastra tidak terdapat di kelas I. Materi sastra Indonesia terdapat di kelas I sampai VI. Setiap kelas tersebut mendapatkan satu materi sastra yang sama untuk satu tahun ajar, dengan penekanan dua aspek pada satu materi tersebut. Contohnya adalah untuk kelas enam terdapat materi teks cerita fiksi dan siswa harus menggali informasi dari teks cerita fiksi tersebut pada pertemuan pertama, juga mengolah dan menyajikan teks tersebut pada pertemuan selanjutnya.

Pembelajaran sastra merupakan materi yang diperlukan oleh siswa. Melalui pembelajaran sastra, bukan hanya aspek kognitif siswa saja yang terlatih, namun aspek afektif pun akan tergali. Seperti yang dipaparkan dalam KBK dan KTSP, pembelajaran sastra dimaksudkan pula untuk memperhalus budi pekerti. Selain itu, dengan mempelajari karya sastra Indonesia, siswa pun dilatih untuk menghargai dan membanggakan sastra Indonesia sebagai khasanah budaya dan intelektual manusia Indonesia. Oleh karena itu, materi sastra Indonesia yang termuat dalam pembelajaran Bahasa Indonesia memiliki peranan yang sama penting dengan materi lainnya.

\section{Analisis Buku Siswa dan Buku Guru Sekolah Dasar berdasarkan Kurikulum 2013}

Buku siswa dan buku guru disediakan untuk memudahkan pembelajaran. Kedua buku tersebut adalah salah satu sumber belajar yang dapat dijadikan rujukan bagi siswa dan guru dalam melaksanakan kegiatan belajar mengajar. Contoh buku siswa dan buku guru yang disediakan oleh Kemdikbud saat ini masih terbatas untuk kelas I dan kelas IV saja. Hal tersebut dimaksudkan untuk mewakili kelas rendah dan kelas tinggi pada jenjang sekolah dasar. Buku siswa dan buku guru yang dianalisis dalam penelitian ini adalah buku untuk kelas IV.

Struktur isi buku kelas IV SD tersusun dengan baik, mulai dari jilid buku hingga halaman terakhir. Karena buku siswa dan buku guru SD berbasis pembelajaran tematik integratif, maka analisisnya menyangkut semua mata pelajaran yang terkait. Berikut adalah hasil analisis buku siswa dan buku guru kelas IV SD Kurikulum 2013.

1. Buku Siswa

Berikut ini adalah hasil analisis buku siswa kelas IV sekolah dasar dalam Kurikulum 2013.

a. Pada semester I terdapat 4 tema. Setiap tema terdiri atas 4 subtema. Masing-masing subtema diuraikan menjadi 6 pembelajaran. Setiap pembelajaran dialokasikan untuk diselesaikan dalam 1 hari. 4 subtema direncanakan selesai dalam waktu 4 minggu. Aktivitas minggu IV berupa berbagai kegiatan yang dirancang sebagai aplikasi dari keterpaduan gagasan pada subtema 1-3. Menurut Kemdikbud (2013), berbeda dengan subtema 1-3, kegiatan minggu IV diarahkan untuk mengasah daya nalar dan berpikir tingkat tinggi. Kegiatan dirancang untuk membuka kesempatan bertanya dan menggali informasi yang dekat dengan keseharian siswa.

b. Materi yang terdapat di dalam buku sesuai dengan KI, KD, dan Indikator yang dibidik. Berikut ini adalah contoh kesesuaian dan keberkaitan hal-hal tersebut.

1) Pada mata pelajaran $P K N$, terdapat $K D$ menunjukkan perilaku bersatu sebagai wujud keyakinan bahwa lingkungan sebagai bagian dari NKRI. Hal tersebut diakutalisasikan di dalam buku siswa dengan adanya tugas untuk mempraktikkannya dengan mengumpulkan lidi dalam jumlah banyak. Lidi tersebut kemudian disatukan menjadi sapu. Hal tersebut bertujuan agar siswa menyadari bahwa ketika masyarakat yang terpisah-pisah bersatu maka akan terjalin persatuan dan kesatuan bangsa. 
2) Pada mata pelajaran Bahasa Indonesia, terdapat KD mensyukuri karunia Tuhan yang maha Esa bahwa memiliki bahasa Indonesia untuk mempermudah dalam berkomunikasi. Hal tersebut diaktualisasikan di dalam buku siswa dengan adanya tugas untuk melakukan wawancara dengan masyarakat sekitar mengenai karya seni dalam masyarakat. Hal tersebut bertujuan agar siswa mensyukuri anugerah yang telah diberikan Tuhan karena mereka memiliki bahasa Indonesia sehingga dapat berkomunikasi meskipun dari suku yang berbeda-beda.

3) Pada tema indahnya Kebersamaan dengan subtema bersyukur atas keberagaman, materi yang dipilih sudah sesuai dengan isi kurikulum. Contoh hal tersebut adalah dengan adanya penugasan, seperti siswa bekerja kelompok yang terdiri atas 6-8 orang. Setiap kelompok diminta membuat skenario drama tentang Bersyukur atas Keberagaman. Siswa ditugaskan untuk membuat drama sesuai tema yang telah ditentukan.

4) Pada setiap akhir pembelajaran, terdapat kolom "Kerjasama dengan Orang Tua". Kolom tersebut berisi tugas yang harus dilakukan siswa bekerja sama dengan orang tuadi rumah. Hal tersebut bertujuan agar orang tua terlibat dalam aktivitas belajar anak. Kejelasan petunjuk di dalam buku guru dan buku siswa diuraikan sebagai berikut.

c. Petunjuk untuk siswa dideskripsikan dengan bahasa yang jelas. Selain jelas, bahasa yang digunakan pun cukup sederhana, sesuai dengan tingkat perkembangan bahasa anak SD. Hal tersebut menyebabkan siswa mudah memahami petunjuk-petunjuk, baik dalam bentuk pernyataan maupun pertanyaan.

d. Bahan ajar (wacana, lagu, dll.) yang tedapat di dalam buku siswa sudah sesuai dengan tema yang disajikan. Selain itu, bahan ajar yang disajikan juga sesuai dengan tingkat perkembangan (kognitif dan psikologis) siswa SD. Contoh hal tersebut adalah wacana yang berjudul "Fahombo Batu dan Situs Trowulan" telah sesuai dengan tema "Indahnya Kebersamaan" dengan subtema
"Kebersamaan dalam Keberagaman". Wacana tersebut mengulas peninggalan bersejarah yang menunjukkan keberagaman suku dan budaya di Indonesia. Wacana tersebut dihadirkan dengan bahasa yang sederhana, yang sesuai dengan tingkat kognitif dan psikologis siswa kelas IV SD., sehingga mudah dipahami siswa.

e. Kegiatan (tugas) siswa yang dihadirkan di dalam buku siswa sudah dapat menggali potensi siswa. Hal tersebut karena kegiatan yang diminta sudah sesuai dengan aspekaspek pada kompetensi dasar. Kegiatan tersebut merupakan kegiatan saintifik, yaitu mengamati, bertanya, menalar, mencoba, mengolah, menyajikan, menyimpulkan, mengkomunikasikan kegiatan (tugas) dalam kegiatan pembelajaran. Sebagai contoh, pada tema "Indahnya Kebersamaan" dengan subtema "Kebersamaan dalam Keberagaman", terdapat tugas siswa diminta untuk mewawancarai masyarakat sekitar tentang pekerjaan dan kegiatan yang berkaitan dengan hasil karya seni dan budaya. Tugas ini mengacu pada kompetensi dasar Bahasa Indonesia, yaitu menggali informasi dari teks wawancara tentang jenisjenis usaha dan pekerjaan serta kegiatan ekonomi dan koperasi dengan bantuan guru dan teman dalam bahasa Indonesia lisan dan tulis dengan memilih dan memilah kosakata baku.

\section{Buku guru}

Buku guru yang diberikan sebagai panduan bagi guru dalam melaksanakan pembelajaran disajikan sama menariknya dengan buku siswa. Baik buku siswa maupun buku guru, penuh dengan gambar ilustrasi yang menarik. Buku guru berisi berbagai hal, seperti petunjuk penggunaan buku guru, rincian materi dan aktivitas pembelajaran yang terdapat di buku siswa, alternative aktivitas yang dapat dilakukan dalam pembelajaran, jejaring tema dan subtema, sampai dengan rubrik penilaian aktivitas dan hasil belajar siswa. Buku ini memudahkan guru untuk melaksanakan aktivitas pembelajaran yang terdapat di dalam buku siswa dengan lebih maksimal. 
Aplikasi Kurikulum 2013 pada Jenjang Sekolah Dasar di Provinsi Banten

Kurikulum 2013 belum sepenuhnya diaplikasikan di sekolah-sekolah. Sekolahsekolah yang telah mengaplikasikan adalah sekolah yang ditunjuk sebagai percontohan bagi sekolah yang lain. Di provinsi Banten, belum banyak SD yang telah mengaplikasikan Kurikulum 2013. Selain itu, belum banyak pula guru SD yang menguasai Kurikulum 2013 sehingga hal tersebut menjadi satu hambatan dalam pengaplikasiannya. Hal tersebut dapat terlihat dari hasil angket yang telah disebarkan kepada 100 orang guru SD di kota Serang, kabupaten Serang, kota Cilegon, dan kabupaten Pandeglang. Berikut ini adalah data hasil observasi dan angket.

1. Sebanyak 5 orang atau $5 \%$ guru sekolah dasar di Provinsi Banten pernah mengikuti sosialisasi/ pelatihan Kurikulum 2013. Hal tersebut menunjukkan bahwa masih sangat banyak guru sekolah dasar yang belum pernah mengikuti sosialisasi/ pelatihan Kurikulum 2013

2. Sebanyak 43 orang atau $43 \%$ guru sekolah dasar di Provinsi Banten memberikan infromasi bahwa di instansi tempat guruguru tersebut bekerja pernah ada yang mengikuti sosialisasi/ pelatihan Kurikulum 2013. Meskipun hampir sebagian besar besar intansi tempat responden bekerja pernah mengirimkan guru untuk pelatihan, namun hal tersebut tidak dapat dijadikan landasan bahwa terdapat 43 instansi yang pernah mengirimkan perwakilannya untuk mengikuti pelatihan. Hal tersebut disebabkan banyak responden yang berasal dari instansi yang sama.

3. Sebanyak 82 orang guru atau $82 \%$ beranggapan bahwa yang dimaksud dengan Kurikulum 2013 adalah kurikulum dengan pembelajaran tematik. Hal tersebut mengindikasikan bahwa selain berkaitan dengan pembelajaran tematik, sebagian besar guru belum mengetahui hal-hal lain mengenai Kurikulum 2013.

4. Sebagai 75 orang guru atau $75 \%$ berpendapat bahwa Kurikulum 2013 adalah kurikulum yang bagus. Hal tersebut menunjukkan tanggapan yang positif, namun sayangnya tanggapan positif tersebut tidak disertai dengan pengetahuan yang baik mengenai kurikulum tersebut.

Dari data tersebut tampak bahwa Kurikulum 2013 pada jenjang sekolah dasar belum diaplikasikan secara menyeluruh di Indonesia, khususnya di provinsi Banten. Sosialisasi mengenai hal tersebut juga belum dilakukan sepenuhnya, sehingga banyak guru yang belum memahami serta menguasainya. Hal tersebut sangat disayangkan, karena sebagai tonggak utama, seharusnya guru menguasai kurikulum tersebut agar dapat diaplikasikan dengan maksimal ketika melakukan pembelajaran di dalam kelas.

\section{SIMPULAN}

Kurikulum 2013 merupakan kurikulum baru yang diterapkan di Indonesia. Kurikulum tersebut disiapkan untuk membentuk generasi yang siap menghadapi tantangan masa depan. Kurikulum 2013 dirancang dengan ideal untuk mengembangkan sikap keagamaan, sikap social, pengetahuan, dan penerapan pengetahuan bagi siswa.

Pada struktur kurikulum 2013 jenjang sekolah dasar, pembelajaran Bahasa Indonesia mendapatkan porsi yang lebih besar dibandingkan dengan sebelumnya. Bahasa Indonesia memiliki peran sebagai pengehela untuk mengantarkan materi pada semua mata pelajaran. Pada Kurikulum 2013, mata pelajaran Bahasa Indonesia mengalami perubahan yang cukup besar, misalnya pembelajaran yang dilakukan berbasis pada teks dan disajikan dalam bentuk tematik integratif untuk semua tingkat kelas. Selain itu, peribahan pun tampak pada penyajian materi kebahasaan dan kesastraan Indonesia. Kedua materi tersebut mendapatkan porsi yang lebih sedikit dibandingkan dengan sebelumnya. Hal tersebut sangat disayangkan, karena kedua materi tersebut merupakan materi yang memiliki peranan yang penting dalam mata pelajaran Bahasa Indonesia.

Pada kurikulum 2013, depdikbud telah menyediakan buku siswa dan buku guru untuk menunjang pembelajaran. Buku siswa dan buku guru tersusun dengan baik, dari mulai penyusunan petunjuk penggunaan, pemilihan materi ajar, penyusunan tugas dan latihan bagi siswa, sampai dengan penilaian. Kedua buku 
tersebut dapat menjadi salah satu penunjang keberhasilan pembelajaran bila digunakan secara tepat dan maksimal.

Kurikulum 2013 dirancang untuk menghadirkan pembelajaran yang ideal, sehingga menghasilkan output yang ideal pula. Rancangan yang telah disusun dengan sempurna tidak akan berakhir dengan sempurna bila dalam aplikasiannya tidak maksimal, begitu pula dengan Kurikulum 2013. Kurikulum 2013 belum dapat diaplikasikan dengan maksimal karena berbagai hal, salah satunya adalah penguasaan guru terhadap kurikulum tersebut belum optimal. Sosialisasi dan pelatihan bagi guru untuk menyokong hal tersebut belum dilakukan secara meraka. Hal tersebut menyebabkan banyak guru yang kurang tepat atau bahkan salah mengaplikasikan Kurikulum 2013. Hal tersebut tentu dapat diatasi dengan adanya sosialisasi dan pelatihan yang menyeluruh dan intensif, sehingga Kurikulum 2013 dapat mencapai tujuan dan hasil yang maksimal.

\section{REFERENSI}

Depdikbud. (2006). Kurikulum Tingkat Satuan Pendidikan. Jakarta: Depdikbud.

Depdikbud. (2013). Kurikulum 2013. Jakarta: Depdikbud.

Puskur Balitbang Depdiknas. (2002). Kurikulum Berbasis Kompetensi Mata Pelajaran Bahasa Indonesia SD. Jakarta: Depdiknas.

Sukmadinata, Nana Syaodih. (1999). Pengembangan Kurikulum: Teori dan Praktik. Bandung: Remaja Rosdakarya. 